\title{
ISLAM TRANSNASIONAL DAN MASA DEPAN NKRI: Suatu Perspektif Filsafat Politik
}

\author{
Irfan Noor \\ Jurusan Akidah-Filsafat Fakultas Ushuluddin IAIN Antasari. \\ Jl. A. Yani Km 4,5 Banjarmasin. \\ Diterima 15 November 2010/Disetujui 17 Desember 2010
}

\begin{abstract}
Tulisan ini membahas fenomena kehadiran organisasi-organisasi Islam radikal transnasional di ruang bangsa Indonesia dalam kurun 10 tabun pasca reformasi. Dalam konteks transisi demokrasi, fenomena ini merefleksikan tendensi kepada pembentukan "komunalisme agama" bercorak teokratik di atas realitas masyarakat yang majemuk, sesuatu yang sangat bertentangan dengan prinsip-prinsip demokrasi yang menjadi "spirit" awal gerakan reformasi. Secara geneologis, kehadiran Islam transnasional tidak bisa dilepaskan dari peran DDII yang menjadi wadah persemaian ideologi Salafi abad 20 yang tidak hanya menekankan pemurnian keagamaan semata, tapi menjadi ideologi alternatif atas modernisme, sekularisme, dan kapitalisme melalui eksperimentasi negara Islam lintas bangsa. Walaupun kehadiran Islam model ini ditengarai akan berpotensi menjadi penyebab perpecahan bangsa, namun penanganannya bukan sepertipengalaman Orde Baru tetapi melalui pendekatan bukum dan strategi de-radikalisasi yang sistematik.
\end{abstract}

Kata Kunci: Islam Transnasional, reformasi, de-politisasi Islam.

\section{Pendahuluan}

Salah satu arus balik reformasi yang bisa kita saksikan dalam kurun waktu 10 tahun pasca reformasi adalah maraknya gerakan Islam radikal berkarakter transnasional di berbagai daerah. ${ }^{1}$ Dianggap sebagai arus balik

\footnotetext{
${ }^{1}$ Nurrohman dan Marzuki Wahid, "Politik Formalisasi Syari'at Islam dan Fundamentalisme Islam”, dalam Jurnal Penelitian Direktorat Perguruan Tinggi Agama Islam, Istigro', Vol. 01, No. 01, 2002, h. 45. Gerakan Islam radikal transnasional yang dimaksud adalah gerakan Islam yang muncul dalam 10 tahun ini yang memiliki agenda kerja "pemberlakuan syari'at Islam" dalam kehidupan umat Islam dan berupaya untuk "memformalkan" syari'at
} 
reformasi karena gerakan ini bertendensi membentuk "komunalisme agama" bercorak teokratik di atas realitas masyarakat yang majemuk, sesuatu yang sangat bertentangan dengan prinsip-prinsip demokrasi yang menjadi "spirit" awal gerakan reformasi.

Kemunculan kelompok-kelompok Islam radikal transnasional di Indonesia pasca Orde Baru ini, memang, memancing debat terbuka di kalangan para ahli. Persoalannya, secara praktek, hampir di semua masyarakat muslim muncul anggapan bahwa agama berkaitan dengan persoalan publik. Anggapan bahwa agama hanya menjadi urusan pribadi seperti yang telah terjadi di sebagian negara di Eropa Barat, tampaknya tidak berlaku untuk masyarakat muslim. Oleh karena itu, dengan menguatnya fenomena ini di ranah kebangsaan kita saat ini, maka fenomena ini telah menandai salah satu ciri dari proses transisi demokratis yang sedang berjalan di negeri ini, di mana sebelumnya di era Orde Baru fenomena ini sangat ditabukan.

\section{Amburadulnya Reformasi dan Politik Identitas}

Mengapa reformasi mengalami "arus balik" ? Menurut Lipset ${ }^{2}$ dan O'Donnell dan Schmitter, ${ }^{3}$ pemerintahan baru yang berada dalam proses transisi demokrasi dari sistem pemerintahan otoriter ke sistem pemerintahan demokratis cenderung tidak memiliki stabilitas dengan legitimasi yang kuat di masyarakat. O'Donnell dan Schmitter bahkan pernah mengingatkan bahwa transisi demokrasi adalah "perubahan dari satu rezim otoriter menuju 'sesuatu yang lain' yang belum jelas". ${ }^{4}$ Wajah-wajah yang lain itu bisa berwujud tegaknya sebuah demokrasi politik atau malah sebaliknya. Artinya, sejalan dengan proses transisi demokrasi yang menawarkan kebebasan yang sangat luas sebagai antitesis pemerintahan otoriter masa lalu, pemerintahan baru yang ingin dibangun dalam konteks

Islam ke dalam batang tubuh sistem negara, yang tujuan akhirnya adalah perubahan dasar negara untuk menjadi "negara Islam" dalam pengertian kekhilafahan internasional.

${ }^{2}$ Seymour Martin Lipset, Political Man; The Social Bases of Politics, (Maryland: Baltimore, 1981).

${ }^{3}$ Guillermo O'Donnell \& Philippe C Schmitter, Transitions from Authoritarian Rule, (Baltimore: The Johns Hopkins University Press, 1986).

${ }^{4}$ O'Donnell, Transitions from Authoritarian...., h. 89. 
ini cenderung memiliki ciri yang tidak stabil dan "gamang", sehingga euforia kebebasan berjalan bebas tanpa adanya kontrol dari negara. Situasi ini benar-benar terefleksi ketika Indonesia selama tahun-tahun pertama reformasi memasuki suasana yang governmentless dan lawless. Pemerintah tidak berwibawa, hukum tidak berjalan, sistem tidak bekerja, membuat masyarakat tidak sabar.

Salah satu "wajah lain" yang umum berkembang adalah politik identitas. Politik identitas Islam pasca Orde Baru ini sebenarnya dapat dibaca dalam tiga fase utama, yaitu "konflik antaragama" di Maluku dan Poso, proyek Islamisasi ruang publik kebangsaan, dan penyerangan terhadap aliran sesat dan anti kristenisasi. ${ }^{5}$

Konflik antarumat beragama di Maluku dan Poso merupakan fase pertama politik identitas Islam pasca Orde Baru. Konflik horizontal bernuansa agama yang terjadi sepanjang tahun 1997 hingga berpuncak di Maluku dan Poso yang berakhir tahun 2002. Konflik ini telah mengubah cara pandang keagamaan dan ketegangan masyarakat di seluruh Indonesia, sehingga melegitimasi muncul sejumlah organisasi Islam beraliran radikal. Diawali oleh Front Pembela Islam (FPI) yang berdiri tahun 1998 di Jakarta, bermunculan organisasi Islam lainnya, seperti Gerakan Islam Reformis (GARIS) di Cianjur tahun 1998, Tholiban di Tasikmalaya tahun 1999, Majelis Mujahidin Indonesia di Yogyakarta tahun 2000, dan Forum Umat Islam (FUI) di Jakarta tahun 2005. Dalam konteks lahirnya organisasi Islam tersebut, lahir juga organisasi Islam yang bersifat transnasional. Tercatat, Forum Komunikasi Ahlussunah Waljamaah (FKASWJ) yang kemudian melahirkan Laskar Jihad (1999), Ikhwanul Muslimin, dan Hizbut Tahrir. Kehadiran organisasi Islam ini menandai gerakan baru Islam di Indonesia yang berbeda dengan organisasi-organisasi Islam yang lebih dulu hadir, seperti Muhammadiyah, Persatuan Islam (Persis), Nahdlatul Ulama (NU), al-Irsyad, Jami'atul Khoir, dan lain-lain.

Selanjutnya, fase kedua politik identitas Islam pasca Orde Baru adalah Islamisasi ruang publik bangsa dalam bentuk penegakan Syari'at Islam. Upaya Islamisasi ruang publik bangsa tampak secara kasat mata dalam

${ }^{5}$ Ismail Hasani, et.all., Radikealisme Agama di Jabodetabek \& Jawa Barat Implik.asinya terhadap Jaminan Kebebasan Beragama/Berkeyakinan, (Jakarta: SETARA Institute, 2011). 
konstelasi politik pasca runtuhnya rezim Orde Baru pada tahun 1998, ${ }^{6}$ dimana modus operandinya dimulai dari polemik nasional di Sidang Tahunan MPR pada tahun 1999 dan terus menggelinding pada Sidang Tahunan berikutnya tentang desakan dicantumkan kembali tujuh kata yang pernah dicoret dari Piagam Jakarta, yakni "dengan kewajiban menjalankan Syari'at Islam bagi pemeluknya”, ke dalam konstitusi Republik Indonesia, UUD 1945. ${ }^{7}$ Setelah mengalami kegagalan di tingkat nasional ini, muncul skenario baru dalam perjuangan penegakan Syari’at Islam, yakni perjuangan di tingkat daerah melalui pencantuman ke dalam Peraturan Daerah (Perda) atau peraturan perundang-undangan lain di tingkat daerah, ${ }^{8}$ terutama di tingkat kabupaten/kota. Karenanya sejak tahun 2000-2009, muncul berbagai Perda Syariah yang mengatur kesusilaan, seperti busana muslim/muslimah, pandai membaca al-Qur'an, khulwat, miras, pelacuran dan perjudian.

'Jamhari dan Jajang Jahroni, Gerakan Salafi Radikal di Indonesia, Jakarta: Rajawali Press, 2004), h. v.

${ }^{7}$ Secara historis, di Indonesia, pembicaraan tentang posisi Syari'at Islam dalam konstitusi, setidak-tidaknya, pernah dibicarakan dalam lima kali kesempatan, yakni: pada sidang BPUPKIPPKI tahun 1945, sidang Majelis Konstituante tahun 1956-1959, Sidang Umum MPRS tahun 1966-1968, Sidang Tahunan MPR tahun 2000, dan Sidang Tahunan MPR tahun 2001. Lihat Arskal Salim, Partai Islam dan Relasi Agama - Negara, (Jakarta: Pusat Penelitian IAIN Jakarta, 1999), h. 8-11.

${ }^{8}$ Diawali di Bekasi, hingga kini Perda bernuansa Syariat Islam8 bertebaran di lebih dari 22 Kabupaten dan kota se-Indonesia. Berbeda dengan Nanggroe Aceh Darusalam (NAD) yang melaksanakan Syariat Islam secara formal berdasarkan Undang-Undang Otonomi Khusus Aceh, maka implementasi di 22 Kabupaten/kota di atas rata-rata menerapkan Anti Maksiat, Kewajiban Berjilbab, ataupun Fasih baca Alquran melalui Peraturan Daerah. Daerah-daerah tersebut antara lain, Provinsi Banten, Provinsi Riau, Provinsi Gorontalo, Provinsi Sumatera Barat, Kota Makasar, Kota Ternate, kota Palembang, Kabupaten Banjar (Martapura), kabupaten Serang, kabupaten Tasikmalaya, kabupaten Sukabumi, kabupaten Cianjur, dan kabupaten Garut. Bahkan, empat kabupaten yang disebut terakhir, secara demonstratif, telah mendeklarasikan "pemberlakuan syari'at Islam" pada 1 Muharram tahun 2001. Lihat Nurrohman dan Marzuki Wahid, "Politik Formalisasi Syari'at Islam dan Fundamentalisme", dalam Jurnal Istiqro', Vol. 01, No. 01, 2002, (Jakarta: Dir.Pertais, 2002), h. 47; dan Majalah Tempo edisi 8, 14 Mei 2006. Penamaan Perda Bernuansa Syariat menjadi Perda Syariat atau Peraturan Daerah bernuansa Syariat Islam mulai digunakan pada saat sebuah interupsi di DPR RI dalam sebuah Sidang Paripurna oleh Constant Ponggawa yang kemudian diikuti dengan sebuah surat permohonan kepada Ketua DPR RI agar menyurati Presiden RI guna mencabut dan membatalkan Perda bernuansa syariat Islam tersebut. Surat tersebut dikeluarkan pada tanggal 17 Mei 2006 yang kemudian dalam pemberitaan Pers selanjutnya sering disingkat menjadi Perda Syariat saja. Lihat juga uraian Audy WMR Wuisang dalam http://audywuisang.blogspot.com / 2007/05/ perda-syariat-vs-nasionalisme-indonesia. html. 
Fase kedua dari politik identitas Islam pasca Orde Baru ini berbarengan dengan munculnya partai-partai politik dengan berbagai aliran. ${ }^{9}$ Di Pemilu 1999, ikut bersaing 48 partai politik. Tercatat 11 partai Islam ikut bersaing di Pemilu 1999, seperti PBB (Partai Bulan Bintang), PK (Partai Keadilan), PKU (Partai Kebangkitan Umat), PNU (Partai Nahdlatul Ummat), PUI (Partai Umat Islam), Partai Masyumi Baru, PSII, PSII 1905, Masyumi (Partai Politik Islam Masyumi), dan PP (Partai Persatuan), dan PPP (Partai Persatuan Pembangunan).

Sementara fase ketiga dari politik identitas Islam pasca Orde Baru adalah penyerangan terhadap aliran sesat, anti kristenisasi, dan anti maksiat. Sasaran utama yang dituju adalah Jemaat Ahmadiyah dan aliran sesat lainnya (Lia Eden dan Mushaddiq), tempat-tempat ibadah umat Kristen, dan tempat-tempat serta praktik yang dianggap maksiat. Penyerangan kelompok Islam radikal terhadap Jemaah Ahmadiyah di Parung merupakan aksi induk yang pada gilirannya menjalar ke daerah-daerah lainnya.

Dinamika yang begitu terasa dari fenomena ini adalah munculnya mainstreaming penegakkan syariat Islam secara radikal, sehingga sering disebut dengan "radikalisme". Indikator utamanya adalah kemunculan kelompok-kelompok atau organisasi-organisasi yang keras dan cenderung tanpa kompromi untuk mencapai agenda-agenda tertentu yang berkaitan dengan kelompok muslim tertentu, atau dan bahkan dengan pandangan dunia (world view) Islam tertentu. Kelompok-kelompok yang masuk dalam kategori radikal ini antara lain Jundullah (tentara Allah), Laskar Jihad, dan Hizbullah (partai Allah) atau organisasi yang kelihatan lebih besar, seperti Front Pembela Islam (FPI). ${ }^{10}$ Ironisnya, gerakan baru ini sudah merambah kelompok Islam tradisionalis, terutama ulama dan santri pesantren. Basis massa yang dulunya direkrut dari para pemuda dari berbagai latar belakang (pengangguran, preman, pemuda fanatik), kini bercampur dengan anakanak muda pesantren yang digerakkan oleh para ulama.

${ }^{9}$ Di Pemilu 1955, Lance Castle dan Herbeth Feith membagi aliran politik ke dalam lima aliran: sosial demokrat, nasionalisme, komunisme, tradisionalisme Jawa, dan Islam. Lihat Lance Castle dalam Lance Castle dan Herbeth Feith, Pemikiran Politik Indonesia (1945-1965), (Jakarta: LP3ES, t.th.), h. Iv.

${ }^{10}$ Azyumardi Azra, "Muslim Indonesia: Viabilitas "Garis Keras" dalam Gatra, edisi khusus 2000, h. 44. 
Gerakan Islam radikal ini, dalam beberapa tahun terakhir ini, menunjukkan kekuatannya sebagai daya tekan (oposisi) kepada rezim yang tidak aspiratif terhadap Islam. Pada titik selanjutnya, isu "negara Islam" dan "syariat Islam" menjadi propaganda krusial tentang relasi Islam dan Negara Kesatuan Republik Indonesia (NKRI) di tengah proses transisi demokrasi bangsa ini.

Dengan menguatnya radikalisme Islam di atas, maka proses transisi demokrasi bisa dikatakan telah mengalami pembusukan dari dalam. Pembusukan ini dikarenakan proses demokratisasi yang dijalankan lebih banyak menitikberatkan pada proses prosedural daripada substansi demokrasi itu sendiri, seperti tegaknya kepastian hukum, good governance, dan sebagainya. Oleh karena itulah, bisa dipahami jika reformasi yang merupakan gerbang masuk utama proses demokratisasi bangsa Indonesia hari demi hari mengalami proses arus balik yang tak terelakkan.

\section{Geneologi Radikalisme Islam Transnasional di Indonesia}

Tampak sekali, radikalisme Islam tidak lahir begitu saja tetapi berdasarkan latar belakang konteks sosial, politik, dan ekonomi yang mendahuluinya. ${ }^{11}$ Namun demikian, adakah faktor teologis dan ideologis yang menjadi dasar perkembangan gerakan Islam ini ?

Munculnya gerakan radikalisme Islam di ranah kebangsaan kita ini sesungguhnya tidak bisa dilepaskan dari kehadiran ideologi Islam beraliran salafisme khas abad 20, ${ }^{12}$ yaitu suatu aliran gerakan Islam yang tidak hanya

\footnotetext{
${ }^{11}$ Khamami Zada, Islam Radikal: Pergulatan Ormas-ormas Islam Garis Keras di Indonesia, (Jakarta: Teraju, 2002), h. 181.

${ }^{12}$ Noorhaidi Hasan, Laskar Jihad: Islam, Militancy and the Quest for Identity in Post-New Order Indonesia. (Ithaca, New York: Southeast Asia Program, Cornell University, 2006), h. 18. Jauh sebelumnya radikalisme Islam awal sesungguhnya dapat ditelusuri pada gerakan kaum Khawarij yang muncul pada masa akhir pemerintahan 'Ali ibn Abî Thâlib dengan prinsipprinsip radikal dan ekstrim dapat dilihat sebagai gerakan radikalisme Islam klasik dalam sejarah.

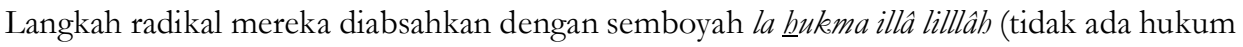
kecuali bagi Allah) dan la hakama illâ Allâh (tidak ada hakim selain Allah) yang dielaborasi berdasar QS. al-Mầidah [5]: 44 yang berbunyi: "wa man lam ya hlkum bimâ anzalallâh faulâikea bum al kâfirûn" (siapa yang tidak menentukan hukum dengan apa yang diturunkan Allah, maka mereka adalah kafir). Karena alasan demikian, kelompok Khawarij tidak mau tunduk kepada Ali dan Mu'awiyah.
} 
menekankan pemurnian keagamaan semata, tapi menjadi ideologi perlawanan terhadap berbagai paham yang tidak sesuai dengan nilai-nilai agama, seperti modernisme, sekularisme, kapitalisme, dan lain-lain. ${ }^{13}$ Tokohtokohnya antara lain, Hasan al-Banna, Sayyid Quthb (Ibkwânul Muslimîn) dan Abu al-A'lâ al-Maududî (Jama'ati Islami).

Secara historis dan visioner, sejarah Islam mengenal gerakan-gerakan Islam radikal yang muncul dalam rangka pemurnian agama. Yang pertama kali ialah gerakan Hanbali yang dipelopori oleh Abu Muhammad alBarbahari. Al-Barbahari dan gerakan Hanbalinya pada awal abad ke-10 menyerukan perlawanan terhadap penyimpangan itu dengan cara kembali kepada aqidah salaf. Gerakan pemurnian kedua juga timbul di kalangan masyarakat Hanbali, yaitu gerakan Ibnu Taimiyyah di Damaskus pada abad ke-14. Ibnu Taymiyyah memandang bahwa Islam telah dikotori oleh tasawuf dan tarekat yang sama sekali tidak berorientasi kepada Sunnah Nabi. Berikutnya, dari gerakan pemurnian ialah gerakan Muhammad ibn 'Abd al-Wahhab pada awal abad ke-19. Ini juga gerakan yang tumbuh di kalangan mazhab Hanbali di Arabia. Gerakan-gerakan pemurnian di masa lalu ditujukan untuk melawan tiga kecenderungan yang terjadi dalam masyarakat Islam. Pertama, ialah rasionalisme Mu'tazilah yang dipandang sebagai aliran yang mengaburkan simplisitas ajaran teologi Islam. Gerakan al-Barbahari pada awal abad ke-10 dengan jelas mewakili usaha pemurnian semacam itu. Kedua, ialah antinomianisme dan spekulatifisme dari gerakan tasawuf. Gerakan pemurnian Ibn Taimiyah menggambarkan perlawanan terhadap

Umumnya, gerakan radikalisme Islam, di samping bersandar pada akar teologi juga menggunakan instrumen yang disebut 'jihad' yang diartikan dengan 'perang'. Konsep jihad ini sering kali dilegitimasi oleh kalangan radikalisme Islam untuk melakukan tindakan kekerasan. Alasan yang sering mendasari jihad secara teologis adalah ayat QS. al-Baqarah [2]: 120: "Tidak akan rela baik Yahudi maupun Nasrani sehingga engkau tunduk kepadanya". Ayat ini dipahami secara literal bahwa orang Yahudi maupun Nasrani adalah pihak yang perlu diwaspadai karena selalu menyerang, terutama terhadap akidah umat Islam. Ayat lainnya yang juga ditengarai sebagai sumber radikalisme Islam terdapat dalam surat al-Taubah [9] ayat 29 yang artinya: "Perangilah orang-orang yang tidak beriman kepada Allah dan hari kemudian, dan tidak mengharamkan apa yang telah diharamkan Allab dan Rasul-Nya dan tidak beragama dengan agama yang benar, yaitu orang yang diberikan al Kitab kepada mereka, sampai mereka membayar jizyah, sedangkan mereka dalam keadaan patub dan tunduk.." Lihat juga Haedar Nashir, Gerakan Islam Syariab: Reproduksi Salafiyah Ideologis di Indonesia, [Seri Disertasi], (Jakarta: PSAP, 2007), h. 204-211.

${ }^{13}$ Jamhari dan Jajang Jahroni, Gerakan Salafi Radikal di Indonesia... h. viii. 
kecenderungan itu. Ketiga, ialah berkembangnya syirik dan khurafat yang melawan konsep tauhid. Perlawanan terhadap kecenderungan ini dilakukan oleh Gerakan Wahhabi. Namun demikian, yang menjadi persoalan adalah bagaimana ideologi salafisme khas abad 20 berkembang di Indonesia?

Sejak zaman pra-kemerdekaan Indonesia, organisasi Islam radikal telah menunjukkan wajahnya yang signifikan mendampingi wajah Islam lainnya. ${ }^{14}$ Jejak-jejak radikalisme Islam di kalangan umat Islam Indonesia bukanlah hal yang sama sekali baru. Di awal abad ke-20, dalam peningkatan semangat nasionalisme melawan kolonialisme Belanda dan deprivasi ekonomi yang kian parah di kalangan pribumi, radikalisme Islam dimunculkan oleh kelompok-kelompok Sarekat Islam (SI) lokal dalam "ideologi" revivalisme Islam; Mahdiisme atau Ratu Adil; dan antikolonialisme. ${ }^{15}$

Sementara dalam konteks Indonesia pasca kemerdekaan, gerakan Islam ini hadir sebagai respon terhadap buruknya pola relasi negara terhadap masyarakat. Oleh karenanya, bila ditelusuri akar radikalisme Islam di Indonesia akan berdahan-ranting cukup kuat dalam gerakan Masyumi dan DDII. Keterkaitan gerakan Masyumi dan DDII dengan radikalisme Islam pasca Orde Baru ini terletak dari peristiwa berpalingnya tokoh-tokoh Masyumi dari arena politik kepada aktivitas dakwah Islam sebagai akibat langsung kebijakan “depolitisasi Islam” era Orde Baru. ${ }^{16}$ Proses berpalingnya

${ }^{14}$ Clifford Geertz, The Religion of Java, (Glencoe: Free Press, 1960). Lihat R. William Liddle, "Skripturalisme Media Dakwah: Suatu Bentuk Pemikiran dan Aksi Politik Islam di Indonesia Masa Orde Baru”, dalam Mark R. Woodward (ed), Jalan Baru Islam, Memetakan Paradigma Mutakbir Islam Indonesia, cet. ke-1, (Bandung: Mizan, 1999), h. 304. M. Syafi'i Anwar, Pemikiran dan Aksi Islam Indonesia, Sebuah Kajian Politik. Tentang Cendekiawan Muslim Orde Baru, (Jakarta: Paramadina, 1995), dan Bahtiar Effendy, Islam dan Negara: Transformasi Pemikiran dan Praktik Politik Islam di Indonesia, (Jakarta: Paramadina, 1999).

${ }^{15}$ Azyumardi Azra, "Muslimin Indonesia: Viabilitas "Garis Keras”, dalam Gatra edisi khusus 2000, h. 44. Gerakan Imran, Warman, pengeboman BCA dan Candi Borobudur dan peristiwa Tanjung Priok adalah bentuk perlawanan umat Islam terhadap pemerintah yang mengakibatkan munculnya radikalisme. Lihat Laporan Tempo, "NII: Islam atau Negara Islam?”, 5 Maret 2000, h. 15

${ }^{16}$ Pada November 1945, Masyumi didirikan sebagai representasi utama tradisi politik intelektual muslim. Tidak seperti Masyumi sebelumnya yang disponsori Jepang, Masyumi sekarang mencakup baik organisasi-organisasi Islam non-politik yang telah bergabung dengan Masyumi pada era Jepang maupun organisasi-organisasi politik Islam pra-pendudukan Jepang, seperti PSII. Selama periode Demokrasi Terpimpin, Masyumi mengalami demoralisasi, terdiskreditkan, terpecah-belah. Sudah sejak Februari 1958, keterlibatan para pemimpin Masyumi 
tokoh-tokoh Masyumi ini berawal dari ditolaknya keinginan mereka untuk merehabilitasi Masyumi oleh pemerintahan awal Orde Baru pada tahun 1967. ${ }^{17}$ Maka sejak saat itu, berkembang paradigma baru para mantan pemimpin Masyumi ini untuk memperluas lingkup perjuangan Islam ke arena-arena non-politik. ${ }^{18}$ Natsir mengungkapkan: "Kita tak lagi mengadakan dakwah dengan cara-cara politik, tetapi terlibat dalam aktivitas-aktivitas politik dengan cara-cara dakwah. Sejak saat itu, istilah "dakwah" menjadi populer dalam ruang publik Indonesia.

Tepatnya 26 Februari 1967, para mantan pemimpin Masyumi ini mengadakan pertemuan di masjid al-Munawarrah (Tanah Abang, Jakarta), yang menghasilkan kesepakatan untuk membentuk Dewan Dakwah Islamiyah Indonesia (DDII). ${ }^{19}$ Karena pengaruh lobi Natsir, DDII dalam perkembangan berhasil mendapatkan akses ke lembaga-lembaga donor dari negara-negara Timur Tengah, seperti Rabithah Alam Al-Islami. Dengan dana dari lembaga ini, DDII mampu membiayai aktivitas-aktivitas dakwah,

dalam pemberontakan PRRI menyebabkan partai tersebut dilarang di daerah-daerah tempat pemberontakan tersebut meletus. Di samping itu, ketidakpercayaan para pemimpin Masyumi terhadap Sukarno dan penolakan Masyumi untuk menerima Manipol-USDEK dan Nasakom, dijadikan dalih bagi Sukarno untuk melarang partai tersebut pada Agustus 1960. Dan sejak 1960 hingga 1966, para tokoh Masyumi yang terlibat dalam pemberontakan PRRI dan yang menentang doktrin-doktrin Sukarno dipenjarakan dengan lama hukuman yang berbeda. Lihat Yudi Latif, Intelegensia Muslim dan Kuasa; Geneologi Intelegensia Muslim Indonesia Abad ke-20, (Bandung: Mizan, 2005), h. 419-20.

${ }^{17}$ Sejak 16 Desember 1965, terbentuk Badan Koordinasi Amal Muslim yang menyatukan 16 organisasi Islam yang bekerja demi direhabilitasinya Masyumi. Dalam menjawab permohonan organisasi-organisasi Islam itu, Suharto menjawab "faktor-faktor legal, politik, dan psikologis telah membuat pihak. Angkatan Darat berpandangan bahwa Angkatan Darat tidak bisa menerima rehabilitasi bekas partai politik Masyumi". Tidak hanya sampai di situ, penolakan rehabilitasi ini kemudian ditindaklanjuti dengan upaya-upaya menghalangi para pemimpin berpengaruh Masyumi dari arena politik praktis dengan membuat stigma bahwa mereka tidak mendukung Orde Baru. Cara-cara seperti ini sempat membuat Muhammad Natsir bersungut dan mengungkapkan kekesalan yang dipendamnya itu dalam sebuah rapat para pemimpin Islam pada 1 Juni 1972 dengan mengucapkan kata-kata: "mereka telah memperlakukan kita seperti kucing kurap".

${ }^{18}$ Yudi Latif, Intelegensia Muslim dan Kuasa ..., h. 497.

${ }^{19}$ Resminya lembaga ini berdiri pada Mei 1967 dengan digawangi oleh Muhammad Natsir dan H. M. Rasyidi sebagai Ketua dan Wakil Ketua. Di samping itu juga, DDII membuat publikasi dakwah, yakni Majalah Media Dakwah. Semua ini dimaksudkan agar DDII bisa memposisikan dirinya sebagai sumber utama dan agen konsultasi bagi dakwah Islam yang efektif di masyarakat modern. Lihat M. Imdadun Rahmat, Arus Baru Islam Radikal: Transmisi Gerakan Revivalisme Islam ke Indonesia (1980-2002), (Jakarta: Erlangga, 2005), h. 83. 
membangun dan melengkapi perpustakaan-perpustakaan di masjid-masjid, universitas-universitas, dan lembaga-lembaga dakwah. DDII juga bereksperimen dengan mengumpulkan pemimpin pesantren, aktivis Islam dan tokoh-tokoh sosial untuk mendirikan pesantren model Ma'bad 'Aly. ${ }^{20}$

Di samping itu, DDII juga mengirim para siswa Indonesia belajar ke Timur Tengah. Hingga 2004, DDII telah mengirim sebanyak 500 mahasiswa ke Timur Tengah dan Pakistan. Para alumnus pendidikan Timur Tengah inilah yang belakangan menjadi aktor utama penyebaran gerakan revivalisme Islam di Indonesia. DDII juga menjadi penggagas serta mediator berdirinya Lembaga Ilmu Islam dan Arab (LIPIA) yang merupakan cabang Universitas Islam Muhammad Ibnu Sa'ud di Riyadh. ${ }^{21}$ Lembaga ini telah meluluskan ribuan alumni yang menjadi agen gerakan Salafi serta aktor penting di kalangan Tarbiyah. ${ }^{22}$

${ }^{20}$ Contoh paling sukses dari eksperimen ini adalah Pesantren Ulil Albab, Bogor, yang berhasil melahirkan tokoh seperti Didin Hafiduddin. Lihat M. Imdadun Rahmat, Arus Baru Islam Radikal..., h. 85.

${ }^{21}$ Upaya membuka cabang di Indonesia diawali dengan datangnya Syekh Abdul Aziz Abdullah al-Ammar, seorang murid tokoh paling penting Salafi, Syekh Abdullah bin Baz ke Jakarta. Oleh bin Baz, ia diperintahkan untuk bertemu dengan Mohammad Natsir. Natsir menyambut baik rencana pendirian lembaga ini dan bersedia menjadi mediator dengan pemerintah Indonesia. Lihat M. Imdadun Rahmat, Arus Baru Islam Radikal..., h. 105.

${ }^{22}$ Yusuf Usman Baisa, alumnus LIPIA ini melanjutkan studi ke Arab Saudi, Afghanistan dan Pakistan, terutama Universitas Islam Imam Muhammad Ibnu Saud di Riyadh. Setelah itu, ia mendirikan pesantren al-Irsyad di Salatiga. Abu Nida yang pada awalnya belajar di madrasah NU di Gresik melanjutkan studi di Akademi Pendidikan Muhammadiyah di Gresik, Pada 1976, ia belajar di Pesantren Karanasem Paciran, Lamongan dan mengikuti rogram DDII di Kalimantan Barat selama dua tahun. Kemudian dipilih menjadi mubalig DDII di Jakarta dan mendapatkan beasiswa melalui DDII untuk belajar kepada guru Salafi di Universitas Islam Imam Muhammad Ibnu Saud di Riyadh. Melalui DDII Riyadh, Abu Nida berkenalan dengan organisasi Kuwait Jamiat Ihya al-Turats alIsami. Setelah lulus 1985, ia pergi ke perbatasan Pakistan-Afghanistan untuk bergabung dengan Jamilur Rahman selama tiga bulan. Lalu ia kembali ke Indonesia untuk mengajar di Pesantren Ngruki pimpinan Abu Bakar Baasyir. Pada 1986 ia menikah dengan santri Ngruki dan pindah ke Sleman Yogyakarta untuk mengajar di pesantren DDII, yaitu Pesantren Ibnul Qoyyim. Ja'far Umar Thalib, pimpinan Laskar Jihad sebelum lulus di LIPIA ia pergi ke Institut Maududi di Lahore, Pakistan dengan bantuan beasiswa DDII pada 1986. Ia juga belajar dan dilatih Jamilur Rahman di perbatasan Pakistan-Afghanistan. Setelah mengajar di Pesantren al-Irsyad yang dipimpin Yusuf Baisa selama dua tahun, ia tinggal di Yaman pada 1991 untuk belajar kepada tokoh Salafi, Syekh Muqbil ibn Hadi al-Wadi di Dammaz. Lihat M. Imdadun Rahmat, Arus Baru Islam Radikal..., h. 108. 
Tak kalah pentingnya, DDII juga melakukan usaha-usaha awal untuk merekrut kader-kader muda dengan tujuan untuk menciptakan para intelektual "organik" bagi gerakan-gerakan dakwah masjid kampus. Rekrutmen kader-kader muda dengan tujuan pelatihan keder dakwah kampus ini bermarkas besar di asrama Perhimpunan Haji Indonesia (PHI) Kwitang Jakarta. Rekrutmen kader-kader muda ini menjadi fenomena 1970an dan 1980-an di Indonesia. ${ }^{23}$

Bersamaan dengan rekrutmen ini, DDII juga memberikan kontribusi pada pengembangan Pesantren dan mengelola hibah dari Timur Tengah untuk mendirikan masjid, terutama masjid-masjid di milieu universitasuniversitas yang prestisius, seperti ITB, UGM dan UI. Dalam konteks ini, DDII menyusun program pelatihan yang diperuntukkan bagi instruktur universitas yang merupakan alumnus berbagai organisasi pelajar Islam. Pada 1974, DDII mengawali usaha yang lebih sistematik berbasis kampus yang disebut Bina Masjid Kampus. Kegiatan Latihan Mujahid Dakwah di Masjid Salman ITB merupakan realisasi dari usaha DDII untuk menjadikan kampus sebagai sasaran dakwah. ${ }^{24}$ Inspirasi bagi penekanan terhadap tauhid dan ghazwul fikr ini diambil dari doktrin gerakan Islam yang terkenal di Mesir, yaitu Ikhwanul Muslimin (IM). ${ }^{25}$

${ }^{23} \mathrm{Di}$ antara rekrutmen awal itu adalah Immaduddin Abdurrahim, Ahmad Sadaly, dan A.M. Luthfi (ITB), Endang Saefuddin Anshari dan Rudy Sjarif (UNPAD), Jusuf Amir Faesal (IKIP Bandung), Daud Ali, Djurnalis Ali, dan Ichtijanto (UNI), A. M. Saefuddin dan Soleh Widodo (IPB), Sahirul Alim dan Amin Rais (UGM), Rofiq Anwar (UNDIP), Daldiri Mangundiwirdjo dan Fuad Amsjari (UNAIR), Gadin Hakim, Bachtiar Fanani Lubis dan Faiz Albar (USU). Lihat Yudi Latif, Intelegensia Muslim dan Kuasa ..., h. 478.

${ }^{24}$ Prototipe gerakan dakwah kampus ini mucul dari masjid Salman ITB yang dikenalkan oleh Immaduddin Abdulrahim melalui paket Latihan Mujabid Dakwah (LMD) sekitar tahun 1974. Yang menarik, materi dasar dari ideologi LMD adalah versi modifikasi dari NDP-nya HMI yang disusun oleh Nurcholish Madjid. Di LMD ini lebih ditekankan doktrin tauhid dan perhatian khusus terhadap ancaman perang pikiran (ghazwulfikr) dengan ide-ide sekuler Barat. Lihat Yudi Latif, Intelegensia Muslim dan Kuasa ..., h. 459.

${ }^{25}$ Di dalam LMD ini, para peserta diharuskan tinggal dalam kompleks masjid Salman selama sekitar seminggu dan diisolasi dari kontak dengan dunia luar. Pelatihan dimulai satu jam sebelum salat subuh dan sepanjang siang, para peserta mengikuti diskusi-diskusi kelompok kecil yang intens dan menantang. Pada malam hari, mereka harus menjalankan salat malam (tabajjud), dan pada malam terakhir mereka harus mengucapkan kalimat syahadat di depan para trainer-nya: "Tidak ada Tuhan selain Allah, dan Muhammad adalah utusan Allah". Pelatihan yang sangat singkat ini ternyata mampu merangsang munculnya kesadaran keagamaan baru 
Program LMD ini berhasil membangkitkan gerakan dakwah masjid kampus yang ditandai dengan lahirnya LDK di beberapa universitas umum di Indonesia. Konon, keberhasilan ini juga membangkitkan gerakan dakwah masjid di luar kampus. Yang terakhir ini ditandai dengan lahirnya Badan Komunikasi Pemuda Masjid Indonesia (BKPMI) di tahun 1977, yang pada tahun 1993 berubah menjadi BKRMI.

Bersamaan dengan gerakan dakwah masjid kampus ini, DDII juga mendorong penerjemahan karya-karya dari pemikir utama gerakan revivalisme Islam Timur Tengah ke dalam bahasa Indonesia, sehingga beredar buku-buku terjemahan karya Hasan Al-Banna, Sayyid Quthb (Ihkwanul Muslimin) dan Abul A’la al-Maududi (Jama'ati Islami). Oleh karenanya, secara tidak langsung, aktivis-aktivis yang terlibat dalam gerakan ini belakangan menjadi tempat persinggahan gerakan dan ideologi Islam dari luar (Islam Transnasional), seperti Ikhwanul Muslimin (Mesir), Darul Arqam (Malaysia), Jama'ah Tabligh (Pakistan), dan Hizbut Tahrir (Yordania). Dari sinilah awal mula perkembangan ideologi Salafisme abad 20 dari Timur Tengah secara lebih intensif di kalangan aktivis muda dakwah di Indonesia.

Dengan masuknya ideologi Salafisme dari Timur Tengah (Islam Transnasional) ini, maka proses pembentukan identitas diri aktivis-aktivis dakwah ini pun makin menemukan bentuknya secara konseptual, dimana mereka mampu mengembangkan diri sebagai bagian dari gerakan yang tidak hanya bersandar pada aktivitas pemurnian keagamaan semata, tapi juga dalam bentuk ideologi perlawanan atas berbagai paham yang tidak sesuai dengan nilai-nilai agama, seperti modernisme, sekularisme, kapitalisme, dan lain-lain. ${ }^{26}$ Percampuran pemikiran Salafi dan Ikhwanul Muslimin yang diambil DDII telah mengubah wajah Islam Indonesia pada periode 1970-an, yakni karakter Islam Indonesia yang radikal.

Ideologi Salafisme yang diterima para aktivis dakwah ini pada saat yang bersamaan menemukan titik-temunya pada serangkaian peristiwa yang dibuat Orde Baru untuk memojokkan para aktivis Islam sepanjang tahun 1970-an hingga 1980-an, dengan puncak peristiwa pada kasus Tanjung

yang radikal. Kelahiran kecenderungan berpikir keagamaan yang baru ini ditandai dengan dikenakannya jilbab oleh para aktivis perempuan, dan dengan cepat, hal ini menjadi simbol gerakan dakwah kampus. Lihat M. Imdadun Rahmat, Arus Baru Islam Radikal..., h. 115.

${ }^{26}$ Jamhari dan Jajang Jahroni, Gerakan Salafi Radikal di Indonesia, .... h. viii. 
Priok di akhir1984. Titik temu inilah yang akhirnya mampu secara efektif menciptakan sikap diri para aktivis sebagai kelompok yang kontra terhadap eksistensi negara sekuler yang diciptakan Orde Baru.

Dengan demikian, pengerasan identitas Keislaman yang mendasari gerakan Islam formalisme di Indonesia terjadi sebagai akibat dari pola relasi negara-masyarakat sipil yang buruk. Oleh karenanya, jika penelusuran atas pola relasi negara-masyarakat sipil tersebut diarahkan kepada mekanisme pemerintahan yang berjalan selama Orde Baru, maka sesungguhnya pola relasi negara-masyarakat sipil yang buruk itu tidak bisa dilepaskan dari bagian kecenderungan rezim ini untuk menempatkan negara sebagai kekuatan determinan dalam rangka mendukung kebijakan utamanya untuk “pembangunan" bangsa ini. ${ }^{27}$ Penekanan pada kebijakan pembangunan ini memang mempunyai landasan dalam sejarah perjalanan bangsa Indonesia. Hal ini karena dari dua dekade perjalanan bangsa ini, sejak kemerdekaan, aspek pembangunan cenderung terabaikan akibat dinamika politik yang tidak terkendali. ${ }^{28}$

Sejak adanya kebijakan yang demikian inilah, maka sejak tahun 1970an, seluruh organisasi sosial politik secara ketat dikontrol melalui sejumlah regulasi. Oleh karenanya, seiring dengan kebijakan itu, masa "politik aliran" yang telah mendominasi politik Indonesia sampai awal tahun 1970-an menjadi berakhir. ${ }^{29}$ Puncaknya adalah melalui sebuah kebijakan tentang asas tunggal Pancasila Indonesia memasuki "era pemurnian ideologi" yang merupakan tahapan paling baru dari perkembangan masyarakat bangsa ini saat itu. ${ }^{30}$ Dengan sendirinya posisi agama di negeri ini secara pelan-

${ }^{27}$ M. Syafi'i Anwar, "Negara dan Cendikiawan Muslim Indonesia Orde Baru”, dalam Saiful Muzani (ed), Pembangunan dan Kebangkitan Islam di Asia Tenggara, (Jakarta: LP3ES, 1993), h. 129 .

${ }^{28}$ M. Dawam Rahardjo, "Islam dan Pembangunan, Agenda Penelitian Sosial di Indonesia”, dalam Saiful Muzani, Pembangunan dan Kebangkitan Islam ..., h. 268.

${ }^{29}$ Muhammad A.S. Hikam, "Negara, Masyarakat Sipil dan Gerakan Keagamaan dalam Politik Indonesia”, dalam Majalah Prisma, No. 3., edisi Maret 1991, (Jakarta: LP3ES), hlm. 78, 83.. Bandingkan dengan Fachry Ali, "Akomodasi Non-Politik Islam Indonesia dalam Struktur Orde Baru”, dalam Majalah Prisma, No. edisi Maret 1991, h. 87-96.

${ }^{30}$ M. Syafi'i Anwar, "Negara dan Cendikiawan Muslim ..., hlm. 129. Apa yang telah dilakukan oleh Indonesia di atas adalah bentuk penerjemahan ideologi developmentalisme menjadi pembangunan melalui mekanisme kontrol ideologi yang ketat dan canggih, baik di bidang sosial, kultural, ekonomi, dan politik. Oleh karenanya, pemerintah dalam rangka melindungi 
pelan tidak lagi mengalami politisasi. Berbagai kebijakan di bidang politik dan ideologi yang digerakkan oleh negara inilah yang akhirnya berimplikasi pada kebijakan depolitisasi Islam dalam sistem politik Orde Baru.

\section{Ideologi Islam Transnasional dan Eksistensi Pancasila}

Dengan runtuhnya rezim Orde Baru dan ditiupkannya “angin kebebasan" di era Orde reformasi, bukan saja menjadi titik balik tetapi juga menjadi jalan lapang bagi gerakan dakwah masjid untuk beroperasi ke ruang publik bangsa. Di sinilah kita sama-sama melihat terjadi perpindahan gerakan aktivis dakwah dari masjid kepada gerakan penegakan syari'at Islam di ruang publik bangsa Indonesia.

Selain karena "angin kebebasan" yang dibawa oleh reformasi, gerakan radikalisme Islam ini juga mendapatkan "tempat"nya di masyarakat lantaran situasi sosial, ekonomi dan politik selama masa reformasi. Situasi ini benarbenar terefleksi ketika Indonesia selama tahun-tahun pertama reformasi memasuki suasana yang governmentless dan lawless. Pemerintah tidak berwibawa, hukum tidak berjalan, sistem tidak bekerja, membuat masyarakat tidak sabar. Ketika demokrasi yang dijalankan untuk keluar dari bentuk-bentuk otoritarianisme negara selama Orde Baru tidak bisa mewujudkan janji-janjinya dalam membentuk masyarakat Indonesia yang lebih baik, maka tawaran ilusif dari kelompok-kelompok Islam dengan basis romatisisme kejayaan masa lalu Islam berkelindan menjadi usaha besar untuk mencari alternatif ideologis dalam membangun masyarakat yang lebih baik. Situasi inilah yang membuat kelompok-kelompok Islam radikal yang selama ini termarjinalisasikan oleh Rezim Orde Baru mengambil alih tugas yang selama ini dilaksanakan oleh pemerintah dengan dalih tugas keagamaan Islam untuk menyelamatkan masyarakat Indonesia. ${ }^{31}$

ideologi pembangunan melakukan pelbagai pendekatan, antara lain: menjalankan kebijakan massa mengambang (the floating mass policy) dan penyebaran ideologi pembangunan melalui pendidikan. Lihat penjelasan lebih lanjut, Mansour Faqih, Analisis Gender..., h. 50-51.

${ }^{31}$ Kecenderungan mencari alternatif di bawah bayang-bayang kegagalan eksperimentasi ideologi modern di negeri ini bisa dilihat dari hasil Survei PPIM-UIN Jakarta Tahun 2001-2004 tentang "Islam dan Konsolidasi Demokrasi di Indonesia", yang menunjukkan bahwa ideologi Islam makin populer karena dianggap memberikan harapan. Kondisi psikologi massa ini tercermin dalam data survei tersebut. Tahun 2001 orang beranggapan bentuk pemerintahan Islam sebagai 
Dengan fenomena perpindahan gerakan aktivis dakwah dari masjid kepada gerakan penegakan syari'at Islam di ruang publik bangsa ini, muncul kekhawatiran akan masa depan kesatuan bangsa ini lantaran gerakan Islam ini ditengerai bisa berpotensi menjadi penyebab perpecahan bangsa.

Dalam konteks filsafat politik, masuknya agama di ruang publik bangsa memang mengundang debat panjang. Latar belakang debat ini, menurut Latif, ${ }^{32}$ terjadinya arus timbal-balik atau "double movement" antara arus sekularisasi dari satu jurusan dan arus Islamisasi dari jurusan lain. Pemikiran filsafat politik liberal (political liberalism) menegaskan bahwa agama sebagai doktrin komprehensif (comprehensive doctrine) perlu dibendung untuk memasuki ruang publik melalui asas sekularisme guna menghindari konflik yang tak terselesaikan. Namun demikian, fakta historis dan sosiologis menunjukkan arus partisipasi agama di ruang publik itu tidak bisa dibendung, meski arus sekularisasi terus berlangsung. Oleh karena itulah, Habermas menganggap perkembangan politik kontemporer saat ini sebagai fase pasca-sekularisme (post-secularism), dimana entitas agama tidak lagi dianggap "barang haram" yang perlu dihindari. ${ }^{33}$ Namun demikian, masuknya kembali agama ke ruang publik memerlukan persyaratan tertentu, yaitu penghargaan dari kedua belah pihak - kaum sekuler dan kaum agama - melalui dialog yang tulus. ${ }^{34}$ Dari situlah, menurut

yang terbaik berjumlah $57,8 \%$. Survei 2002 , jumlah ini melonjak menjadi $67,1 \%$, sementara survei 2004 meningkat lagi menjadi 72,2\%. Ini merupakan indikasi bahwa ideologi Islam semakin diminati. Konsistensi anggapan ini terjadi pula pada aspek-aspek lain. Dengan kata lain, pilihan atas "pemerintahan Islam" tidak berdiri sendiri, ia berkorelasi dengan faktor-faktor lainnya yang berhubungan dengannya. Tidak bekerjanya sistem hukum nasional telah menimbulkan banyak kekecewaan di tengah masyarakat. Hal ini pada gilirannya mendorong orang untuk berandai-andai, mungkin sistem ini sebaiknya digantikan dengan sistem baru yang dapat memenuhi rasa keadilan masyarakat. Syari'at Islam tampaknya memenuhi keinginan masyarakat mengenai sistem hukum yang ideal. Tahun 2001 orang yang menginginkan hukum Islam berjumlah 61,4\%. Tahun 2002, angka ini melonjak menjadi 70,6 \%. Tahun 2004, angka ini meningkat menjadi 75,5\%. Lihat Jamhari dan Jajang Jahroni, Gerakan Salafi Radikal di Indonesia ..., h. 219-220.

${ }^{32}$ Yudi Latif, Negara Paripurna: Historisitas, Rasionalitas, dan Aktualitas Pancasila, (Jakarta: Gramedia, 2011), h. 618.

${ }^{33}$ Giancarlo Bosetti, Iman Melawan Nalar (Perdebatan Joseph Ratzinger Melawan Jurgen Habermas), diterjemahkan oleh Hary Susanto, (Yogyakarta: Kanisius, 2009), h. 5-36.

${ }^{34}$ Jurgen Habermas, Between Facts and Norms: Contribution to a Discourse Theory of Law and Democracy, Transl. by William Rehg, (MIT Press: Paperback Reprint, 1992). 
Rawls, bisa dicapai apa yang disebutnya dengan kesepakatan tumpangtindih (overlapping consensus). ${ }^{35}$

Jika dalam konteks negara modern, kelahiran ideologi sekuler dipandang sebagai doktrin komprehensif yang tidak lagi membutuhkan agama, maka dalam konteks negara Indonesia modern justru lahirnya Pancasila sebagai ideologi negara memberi ruang bagi partisipasi agama, sebagai yang tertuang dalam sila pertama (Ketuhanan Yang Maha Esa). Sila pertama ini sesungguhnya merefleksikan suatu overlapping consensus antara negara dan agama.

Dalam konteks ini, sejak disahkan Pancasila pada 18 Agustus 1945 sebagai dasar negara sekaligus ideologi nasional, posisi Pancasila merefleksikan suatu akomodasi komprehensif terhadap pluralitas yang menjadi ciri bangsa Indonesia sejak berabad-abad. Latar belakang pluralitas inilah, yang mendorong para founding-father bangsa ini untuk merumuskan satu dasar falsafah negara (philosofische grondslag), pandangan hidup (weltanschaunng) dan ideologi nasional yang berfungsi menjadi pegangan dan nilai bersama dalam mempersatukan sekaligus mencapai tujuan bersama di atas pluralitas kebangsaan.

Dengan demikian, isu kehadiran Islam di ruang publik bangsa ini sesungguhnya tidak perlu menjadi debat tidak berkesudahan, namun yang perlu diwaspadai dari fenomena kontemporer gerakan Islam pasca Orde Baru ini adalah dimensi ideologi transnasional dan radikal karena akan mengancam masa depan eksistensi kesatuan bangsa ini lantaran gerakan Islam ini bisa berpotensi menjadi penyebab perpecahan bangsa.

Bagi penulis sendiri, kekhawatiran itu adalah hal yang bisa dipahami. Namun, janganlah ketika kekhawatiran itu muncul, lalu solusi yang kemudian dikembangkan dalam membendung arus gerakan tersebut dengan mengulangi kesalahan yang telah diciptakan oleh Orde Baru. Melalui penjelasan di atas, kiranya cukup jelas bahwa kebijakan "depolitisasi Islam" yang diterapkan Orde Baru justru secara tidak sengaja telah menciptakan "kekuatan baru" bagi kelompok-kelompok Islam berhaluan politik. Modus operandi gerakan dakwah yang dikembangkan para pemimpin tua Masyumi berhasil menciptakan daya resistensi mereka di

${ }^{35}$ John Rawls, Political Liberalism, (New York: Columbia Univ. Press, 1993). 
hadapan hegemoni total negara Orde Baru. Hasilnya, ruang kebebasan era reformasi justru menjadi tempat mereka bermetamorfosis sebagai kekuatan yang sulit dibendung.

Dengan demikian, sudah saatnya kita tidak mengulangi kesalahan Orde Baru. Jika kita ingin mengendalikan gerakan yang ditengerai berpotensi memecah kesatuan bangsa ini, akan lebih baik kita sama-sama mendorong negara ini untuk tampil sebagai kekuatan politik yang mampu mengakomodasi seluruh kekuatan elemen yang ada di masyarakat. Pengalaman Orde Baru bisa menjadi pelajaran berharga bagi kita semua ketika kelompok sosial yang selama ini termarjinalisasi berubah menjadi kekuatan yang sukar untuk diabaikan begitu saja. Pengalaman Orde Baru itu juga menjadi pelajaran bahwa hegemoni tidak serta-merta membuat kelompok sosial yang termarjinalisasikan menjadi kehilangan kekuatan dan musnah begitu saja.

Mungkin benar kata filsuf Perancis Michel Foucault bahwa "tak ada hegemoni yang sedemikian kuatnya sehingga menguras habis sumber-sumber daya untuk melakukan perlawanan". 'Setiap relasi kuasa', katanya, 'mengimplikasikan paling tidak secara potensi adanya suatu strategi perjuangan, ketika dua kekuatan yang berbadapan tidak saling membayangi, tidak kehilangan sifatnya yang spesifik, atau akbirnya tidak pula menjadi kabur. Setiap pihak menjadi semacam batas permanen bagi pibak yang lain, sebuah titik yang mungkin melakukan gerak balik (a point of possible reversal)" ${ }^{36}$ Hujjah ini sudah kita buktikan kebenarannya saat ini !

Dalam konteks diskusi ini, paling tidak ada dua langkah yang perlu kita kembangkan dalam rangka mengantisipasi ideologi transnasional dan radikal dari gerakan Islam pasca Orde Baru.

Pertama, penegakan bukum terhadap setiap tindakan kekerasan atas nama agama: penegakan hukum yang sungguh-sungguh akan mampu memulihkan kepercayaan masyarakat terhadap aparat penegak hukum dan mewujudkan preseden positif bahwa tindak kekerasan atas nama agama atau apapun adalah pelanggaran hukum. Sebagai bagian dari hak untuk bebas berekspresi dan berorganisasi, keberadaan organisasi Islam radikal tetap dibenarkan sepanjang tidak mengekspresikan sikap intoleran yang

${ }^{36}$ Michel Foucault, Power/Knowledge: Wacana Kuasa/Pengetahuan, diterjemahkan oleh Yudi Santoso, (Yogyakarta: Bentang, 2002). 
menimbulkan kekerasan. Tapi jika kekerasan telah menjadi pilihan aksiaksinya, negara harus menindak dan memproses secara hukum.

Kedua, menyusun strategi komprehensif de-radikalisasi anggota dengan membentuk kanal politik bagi elit dan kanal ekonomi bagi anggota: langkah deradikalisasi dilakukan dengan jalan memoderasi pandangan keagamaan dan transformasi anggota menjadi lebih moderat. Bagi elit organisasi Islam radikal, moderasi dapat dilakukan dengan membentuk kanal-kanal politik baru untuk menciptakan titik temu pandangan yang lebih kompromistis dan dalam kerangka demokrasi. Mekanisme demokrasi sangat dimungkinkan untuk memoderasi pandangan radikal menjadi lebih moderat. Sedangkan kanal ekonomi ditujukan bagi para anggota organisasi-organisasi radikal yang umumnya adalah masyarakat di akar rumput dengan tingkat kesejahteraan rendah. Kanal ekonomi akan menjawab kegelisahan masyarakat akar rumput yang selama ini mengalami keterbelakangan ekonomi.

\section{Penutup}

Berdasarkan uraian-uraian di atas, ada beberapa yang dapat ditarik garis kesimpulan. Pertama, gerakan Islam formalisme yang saat ini marak di Indonesia sesungguhnya merupakan "buah manis" dari kebijakan "depolitisasi Islam" Orde Baru yang justru secara tidak sengaja telah menciptakan "kekuatan baru" bagi kelompok-kelompok Islam berhaluan politik. Modus operandi gerakan dakwah yang dikembangkan berhasil menciptakan daya resistensi mereka di hadapan hegemoni total negara Orde Baru. Muaranya, ruang kebebasan era reformasi justru menjadi tempat mereka bermetamorfosis sebagai kekuatan yang sulit dibendung.

Oleh karena itu, jika ingin mengendalikan gerakan yang ditengerai berpotensi memecah kesatuan bangsa ini, maka akan lebih baik bila negara ini didorong sebagai kekuatan politik yang mampu mengakomodasi seluruh kekuatan elemen yang ada di masyarakat melalui penegakkan hukum untuk menjamin keutuhan bangsa dan kemajemukan masyarakatnya [] 


\section{DAFTAR PUSTAKA}

Ali, Fachry. (1991). "Akomodasi Non-Politik Islam Indonesia dalam Struktur Orde Baru", dalam Majalah Prisma, No. edisi Maret.

Anwar, M. Syafi'i. (1993). "Negara dan Cendikiawan Muslim Indonesia Orde Baru", dalam Saiful Muzani (ed.). Pembangunan dan Kebangkitan Islam di Asia Tenggara. Jakarta: LP3ES.

Audy WMR Wuisang dalam http://audywuisang.blogspot.com /2007/ 05/ perda-syariat-vs-nasionalisme-indonesia.html.

Azra, Azyumardi. (2000). "Muslim Indonesia: Viabilitas "Garis Keras" dalam Majalah Gatra, [edisi khusus].

Bosetti, Giancarlo. (2009). Iman Melawan Nalar (Perdebatan Joseph Ratzinger Melawan Jurgen Habermas), diterjemahkan oleh Hary Susanto. Yogyakarta: Kanisius.

Castle, Lance. (t.th.) dalam Lance Castle dan Herbeth Feith. Pemikiran Politik Indonesia (1945-1965). Jakarta: LP3ES.

Effendy, Bahtiar. (1999). Islam dan Negara: Transformasi Pemikiran dan Praktik Politik Islam di Indonesia, Jakarta: Paramadina.

Foucault, Michel. (2002). Power/Knowledge: Wacana Kuasa/Pengetahuan, diterjemahkan oleh Yudi Santoso. Yogyakarta: Bentang.

Geertz, Clifford. (1960). The Religion of Java. Glencoe: Free Press.

Habermas, Jurgen. (1992). Between Facts and Norms: Contribution to a Discourse Theory of Law and Democracy. Transl. by William Rehg. MIT Press: Paperback Reprint.

Hasan, Noorhaidi. (2006). Laskar Jihad: Islam, Militancy and the Quest for Identity in Post-New Order Indonesia. Ithaca, New York: Southeast Asia Program, Cornell University. 
Hasani, Ismail, et.al. (2011). Radikalisme Agama di Jabodetabek \& Jawa Barat Implikasinya terbadap Jaminan Kebebasan Beragama/Berkeyakinan. Jakarta: SETARA Institute.

Hikam, Muhammad A.S. (1991). "Negara, Masyarakat Sipil dan Gerakan Keagamaan dalam Politik Indonesia", dalam Majalah Prisma, No. 3., edisi Maret 1991, (Jakarta: LP3ES).

Jamhari dan Jajang Jahroni. (2004). Gerakan Salafi Radikal di Indonesia. Jakarta: Rajawali Press.

Latif, Yudi. (2005). Intelegensia Muslim dan Kuasa; Geneologi Intelegensia Muslim Indonesia Abad ke-20. Bandung: Mizan.

Latif, Yudi. (2011). Negara Paripurna: Historisitas, Rasionalitas, dan Aktualitas Pancasila. Jakarta: Gramedia.

Liddle, William. (1999). "Skripturalisme Media Dakwah: Suatu Bentuk Pemikiran dan Aksi Politik Islam di Indonesia Masa Orde Baru", dalam Mark R. Woodward (ed.). Jalan Baru Islam, Memetakan Paradigma Mutakhir Islam Indonesia, cet. ke-1. Bandung: Mizan.

Lipset, Seymour Martin. (1981). Political Man; the Social Bases of Politics. Maryland: Baltimore.

Majalah Tempo, (Laporan), “NII: Islam atau Negara Islam?”, Edisi 5 Maret 2000.

Majalah Tempo edisi 8, 14 Mei 2006.

Nashir, Haedar. (2007). Gerakan Islam Syariab: Reproduksi Salafiyah Ideologis di Indonesia, [Seri Disertasi]. Jakarta: PSAP.

Nurrohman dan Marzuki Wahid. (2002). "Politik Formalisasi Syari'at Islam dan Fundamentalisme Islam", dalam Jurnal Penelitian Direktorat Perguruan Tinggi Agama Islam, Istiqro', Vol. 01, No. 01, 2002.

O'Donnell, Guillermo \& Philippe C Schmitter. (1986). Transitions from authoritarian rule. Baltimore: The Johns Hopkins University Press. 
Rahardjo, M. Dawam. (1993). "Islam dan Pembangunan, Agenda Penelitian Sosial di Indonesia", dalam Saiful Muzani (ed.). Pembangunan dan Kebangkitan Islam di Asia Tenggara. Jakarta: LP3ES.

Rahmat, Imdadun. (2005). Arus Baru Islam Radikal: Transmisi Gerakan Revivalisme Islam ke Indonesia (1980-2002). Jakarta: Erlangga.

Rawls, John. (1993). Political Liberalism, New York: Columbia Univ. Press.

Salim, Arskal. (1999). Partai Islam dan Relasi Agama - Negara. Jakarta: Pusat Penelitian IAIN Jakarta.

Zada, Khamami. (2002). Islam Radikal: Pergulatan Ormas-ormas Islam Garis Keras di Indonesia. Jakarta: Teraju. 